\title{
Prinsip Memudahkan Urusan dalam Sosiologi Islam
}

\author{
Zaenal Mutaqin \\ (Department of Fiqh and Usul, Academy of Islamic Studies, University of \\ Malaya;nuruldjaubari@,yaboo.com) \\ Ridzwan Ahmad \\ (Department of Fiqh and Usul, Academy of Islamic Studies, University of \\ Malaya; ridswan@,um.edu.my)
}

\begin{abstract}
The focus of this study is the fiqh of al-taisir Yusuf al-Qaradawi. Yusuf al-Qaradawi is one of the figures highly admired by Islamic law researchers and researchers because his fatwas and views are always up to date and fresh in addition to bis easy and precise language style. The approach he uses is simplicity and ease. But there is a group of Muslims who are disputing the fatwa and the view of figh. Then an investigation is needed regarding the simplicity and ease of thought it carries. This study takes the form of literature based on the analysis of maqasid al-shari'ah. Among the formula analyzed in fiqh al-taisir al-Qaradawi are: the concept of al-taisir figh and a set of premises used in its implementation, including: issues regarding rukhsah, emergency and mitigating circumstances, choose the easy not the careful, limit the problems that are mandatory and haram, free from fanaticism of the school and applying the principle of convenience in difficult problems, in keeping with maqasids and changing fatwas. The author finds from this investigation that the ide of simplicity and ease in Figh al-Taisir al-Qaradawi is still acceptable and can be used as a guide, because the issues that are brought up in the figh of al-taysir are the issues of khilafiyah that are open to conversation not the exact qat'i problem that is certainly. But in the implementation it should not be used on any issues and circumstances, Besides, it should not deviate from the guidelines of the concept of Taisir, initiated by the scholars of the figh and parallel with the Maqasid alShari'ah which became the main reference in the philosophy of Islamic law.
\end{abstract}

\section{Keywords: Islamic legal theory, the goals of law, Sociological thought}

\begin{abstract}
Abstrak
Fokus kajian ini adalah fiqh al-taisir Yusuf al-Qaradawi. Yusuf al-Qaradawi adalah salah seorang tokoh sangat dikagumi oleh para pengkaji dan peneliti hukum Islam karena fatwa dan pandangannya selalu up to date dan segar disamping gaya bahasanya yang mudah dan tepat. Pendekatan yang digunakannya adalah kesederhanaan dan kemudahan. Namun ada sekelompok umat Islam yang mempertikai fatwa dan pandangan fiqhnya. Maka diperlukan adanya satu penyelidikan berkaitan dengan pemikiran kesederhanaan dan kemudahan yang diusungnya. Kajian ini berbentuk literatur yang berbasis analisis dengan maqasid alshari'ah. Antara formula yang dianalisis dalam figh al-taisir al-Qaradawi adalah: konsep fiqh al-taisir dan seperangkat premis yang digunakan dalam pelaksanaanya, meliputi: isu tentang rukhsah, darurat dan keadaan yang meringankan, memilih yang mudah bukan yang berhati-hati, membatasi masalah yang wajib dan haram, bebas
\end{abstract}


dari fanatisme mazhab, menerapkan prinsip kemudahan dalam masalah yang susah dielakkan, penjagaan maqasid dan perubahan fatwa. Penulis mendapati dari penyelidikan ini bahwa ide kesederhanaan dan kemudahan dalam fiqh al-taisir alQaradawi masih bisa diterima dan boleh dijadikan panduan, karena isu yang diusung dalam fiqh al-taysirnya adalah isu-isu khilafiyah yang terbuka dengan perbincangan bukan masalah qat'i yang sudah pasti. Namun di dalam pelaksanaannya tidak boleh digunakan pada setiap isu dan keadaan, disamping itu hendaknya tidak menyimpang dari garis panduan konsep taisir yang digagas oleh para ulama usul fiqh dan sesuai dengan maqasid al-shari'ah yang menjadi acuan utama dalam falsafah hukum Islam.

\section{Kata kunci: teori hukum Islam, tujuan hukum, pemikiran sosiologis}

\section{A. PENDAHULUAN}

Figh al-taisir adalah di antara metode yang digunakan olehYusuf al-Qaradawi dalam mengeluarkan fatwa yang melibatkan berbagai isu yang melanda umat Islam masa kini. Yusuf al-Qaradawi adalah seorang sarjana Muslim yang senantiasa istiqamah dalam menangani isu-isu kontemporer, sehingga pemikiran fiqhnya banyak diminati dan menjadi rujukan para peneliti hukum Islam, karena fatwanya yang aktual dan terkini. Antara sebabnya adalah karena kaedah yang digunakan bertepatan dengan tuntutan masa kini, selain menggunakan bahasa yang mudah difahami dan menarik pembaca yang membedakannya dari tokoh yang lain. Inilah yang sebahagian kelompok menyebut pemikiran fiqh beliau dengan sebutan fiqh al-taisir.

Menurut al-Qaradawi, manusia kini sangat memerlukan kepada kemudahan fiqh (hukum Islam). Kewajiban fiqh masa kini bertujuan untuk menjawab persoalan masyarakat umum (umat) karena setiap masalah yang terjadi dalam kehidupan manusia pasti mempunyai aturan hukum dalam syari'at Islam. Fiqh yang mudah ini adalah sesuatu yang dituntut dalam syariat, bukan hanya sebagai reaksi terhadap tekanan dan tuntutan keadaan atau upaya untuk menyelaraskan diri dengan zaman seperti yang disangkakan oleh sesetengah orang. Syari'at Islam berdiri di atas dasar 
kemudahan bukan kesulitan dan kesukaran (Ghazali, 2013: 90).Pada era baru ini, para sarjana Muslim kontemporer mengambil pelbagai kaedah dan pendekatan dalam mengeluarkan fatwa yang berbeda antara satu tokoh dengan yang lain. Ini sesuai dengan sifat manusia yang mempunyai kecenderungan yang berbeda, guru dan pendidikan yang berbeda, masa dan keadaan yang berlainan. Tetapi perbedaan manhaj dan kaedah ini adalah sesuatu yang diakui dalam Islam (mashru') selagimana bersesuaian dengan metodologi ulama fiqh dan usul fiqh.

Kajian ini dibuat sebagai tindak balas terhadap kritikan yang ditujukan kepada alQaradawi, baik dari segi metodologi fiqh (istinbat hukum Islam) ataupun fatwanya. Terutama dalam hal metode istinbatnya yaitu menggunakan pemikiran wasatiyyah dan figh al-taisir. Oleh itu, kajian terperinci diperlukan untuk mendapatkan pemahaman yang benar dan tepat.

Antara kritikan-kritikan itu seperti yang disampaikan oleh Sulaiman bin Salih alKhurashi mengenai mazhab wasatiyyah yang dipegang oleh al-Qaradawi, dia berkata:

Menanggapi hal tersebut, dapat penulis katakan, babwa pada nukilan sebelumnya, Dr. Yusuf al-Qaradawi telah menyampaikan kepada kita, bahwa ia merupakan salah satu penganut "Aliran Tengah", tetapi ia tidak menjelaskan beberapa sendi yang mendasar aliran ini kepada kita, karena pada dasarnya semua orang telah ikut di dalamnya (segala sesuatu boleh dilakukanya) apalagi orang yang berprinsip "menggampangkan" segala hal yang berkenaan dengan akidah dan fiqh (al-Khurashi, 2003: 22).

Selain itu al-Khurashi juga mengkritik manhaj fiqh al-Qaradawi, dengan menyatakan bahwa: "Aliran ini cenderung "suka menggampangkan" (mengambil mudah) dalam masalah figh, membangun pemikiran 'Islam Universal", cenderung menggunakan akal dalam memahami nas-nas syari'ah, menggunakan istilah ijtibad dan pembaharuan" (alKhurashi, 2003: 23). 
Kritikan juga berasal dari Ahmad bin Muhammad bin Mansur al-'Udaini, katanya:

Manusia telab berbuat jabat terbadap akal tatkala mereka menentang nas-nas al-Qur'an dan sunnah yang sabih, dan menjadikanya turut campur dalam masalah-masalah ghaib, seperti Mu'tazilah dan para pengikutnya di zaman ini dari kalangan 'aqlani (rasionalis). Mereka ini adalah simbol dari pemikiran yang campur baur tanpa ada ketentuan dan ikatan. Sebagian mereka - para 'aqlani - terbitung sebagai para da'i dan para pemikir, sebagian yang lain tergolong sebagai budayawan, cendikiawan dan pengamat.... Contoh dari golongan yang pertama adalah Yusuf al-Qaradawi, murid salah seorang pembesar rasionalis, Muhammad al-Gazali al-Mu'tazili yang celaka. Sungguh si murid telah menempuh jalan gurunya dalam menolak nas-nas dan mencerca nas-nas tersebut manakala bertentangan dengan akalnya yang sakit hanya saja sang guru terang-terangan dalam mencerca nas-nas. Si murid sendiri menyimpulken hal itu dalam akbir kitabnya yang berjudul 'Kaifa Nata'amal Ma'a al-Sunnah al-Nabawiyyah (al-'Udaini, 2011: 225).

Ada juga kritikan dari Ahmad bin Yahya bin Muhammad al-Najmi berkenaan dengan manhaj penyatuan yang dibawa oleh kumpulan Ikhwan al-Muslimin (termasuk al-Qaradawi) demi persatuan dan kesatuan umat. Namun penyatuan antara pandangan mazhab, pemikiran dan aliran ini perlu ada pembahasan yang terperinci bukan semua menggunakan kaedah ini (al-Najmi, 2009).

Oleh karena pelbagai kritikan yang ditujukan kepada al-Qaradawi baik dari segi metode maupun kandungan fatwanya termasuk di dalamnya figh al-taisir, maka kajian tentang fiqh al-taisir beliau secara terperinci diperlukan untuk menghentikan polemik yang berpanjangan dan menghilangkan persepsi negatif terhadap beliau yang mewakili para tokoh dan cendikiawan Muslim, disamping meluruskan kembali sekiranya terdapat sebarang kekeliruan atau kekurangan pada sebagian metode dan fatwanya, demi kebaikan Islam dan kaum Muslimin semuanya. Selanjutnya menggali 
pendekatan dan semangat yang diambil oleh al-Qaradawi dalam penyusunan fiqh altaisimya juga diperlukan agar mendapatkan kejelasan pendekatan yang dipakai.

Dalam artikel ini, penulis mendapati semangat atau pendekatan yang digunakan oleh al-Qaradawi dalam berfatwa adalah menggunakan pendekatan maqasid al-shariah. Atas dasar ini, penulis akan menguraikan bagaimana fiqh al-taisir dalam perspektif alQaradawi? Adakah boleh diterima metode yang digunapakainya yaitu fiqh al-taisir atas dasar menggunakan maqasid? Adakah metode fatwanya masih sesuai dengan pandangan para ulama usul dan maqasid? Apa sahaja formula dari fiqh taisir yang dijadikan panduan fatwanya. Semua pertanyaan itu akan dijawab dalam artikel ini.

\section{B. TINJAUAN PUSTAKA}

\section{Konsep Fiqh al-Taisir}

Konsep fiqh al-taysir merujuk kepada kaedah "Al-mashaqqah tajlibu al-taisir" yang bermaksud: kesempitan dapat menarik kemudahan. Kaedah ini menjelaskan bahawa hukum Islam menginginkan kemudahan. Islam tidak memberi beban kepada seseorang dengan sesuatu yang di luar kemampuanya, dapat menyempitkan atau sesuatu yang tidak sesuai dengan watak dan tabi'at. Allah dan Rasul-Nya menginginkan serta memerintahkan pemeliharaan terhadap kemudahan dan keringanan (al-Suyuti, t.t.: 55).

Sebagian ulama berpendapat bahawa fiqh al-taisir adalah istilah baru yang dicetuskan oleh al-Qaradawi untuk memudahkan pemahaman umat kepada hukum Islam. Sementara jika merujuk pandangan fuqaha dan usuliyyin, (Zahrah, t.t.: 51) maka kita dapati pembahasan tentang kemudahan-kemudahan di dalam Islam. Mereka 
membincangkan tentang rukhsah pada hukum-hukum cabang fiqh (al-Zuhayli, 2005: 51)dalam kitab-kitab mereka dan menyusun kaedah-kaedah berkenaan dengan hukum rukhsah, kemudian mereka ini menyusun ilmu Qawa'id al-fiqhiyyah seperti al-Suyuthi, Ibn Najim dan sederet ulama kontemporer seperti Abd al-Karim Zaydan, Mustafa alZarqa dan lain-lain (al-Suyuti, t.t.: 55; Ibn Najim, t.t.: 83).

Adapun yang menjadi dalil dari kaedah ini, di antaranya: al-Qur'an Surah alBaqarah: 286, al-Nisa: 28, al-Ma'idah: 6 dan al-Hajj: 78. Keseluruhan ayat ini menjelaskan bahawa Islam selalu menginginkan kemudahan bagi manusia. Semua hukum yang ada dalam Islam tidak melampaui kemampuan manusia yang bersifat lemah. Berdasarkan ayat-ayat inilah para fuqaha membentuk kaedah tersebut, lalu dijadikan sebagai cara untuk menyelesaikan berbagai masalah (al-Suyuti, t.t.: 55; Ibn Najim, t.t.: 83; al-Nadwi, 2013: 303).

Dalam tafsir al-Manar, ketika menjelaskan surah al-Baqarah ayat 185, Rashid Rida menyatakan bahwa yang paling baik (ketika bepergian) yang tidak mengalami kesulitan adalah berpuasa, sebab tidak ada 'illat (alasan) keringanan. Akan tetapi jika (dalam bepergian itu) mengalami kesulitan, lebih baik tidak berpuasa, sebab ada illat (alasan) keringanan. Hal ini karena Allah tidak menghendaki kesulitan bagi manusia, malahan sebaliknya. Dia menghendaki kemudahan dan kebaikan bagi mereka. Ketentuan ini merupakan asal (kaedah) agama. Para ulama membentuk kaedah " $A l$ mashaqqah tajlibu al-taisir" (kesulitan dapat menarik kemudahan) dari firman Allah ini (Rida, 1973: 164).

a. Hadis Nabi SAW yang bermaksud: "Agama yang paling dicintai Allah adalah agama yang lurus dan bijak, yaitu Islam." Menurut para ulama, Islam disebut sebagai agama 
yang hanif dan sambah, karena seluruh ajaranya mengandung kemudahan dan keringanan. Islam adalah agama yang bijaksana dalam menerapkan hukum, tidak membebani seseorang di luar kemampuanya.

b. Hadis riwayat Abu Urairah RA, Nabi SAW bersabda yang bermaksud: "Agama (Din) itu mudah; siapa yang memberat-berat agama akan dikalabkanya. Dengan demikian, kalian harus bertindak yang benar, mengikat tali persaudaraan, memberi khabar gembira dan selalu memohon pertolongan Allah di waktu siang maupun malam." (Bukhari, t.t.: 16). Menurut Ibnu Hajar al-'Asqallani (t.t.: I: 101), Allah mengkategorikan Islam sebagai agama yang mudah, jika dibandingkan dengan agama-agama sebelumnya. Bagi umat Islam, Allah telah menghapus semua beban yang dibebankan kepada umat-umat sebelumnya, seperti masalah taubat. Taubat umat terdahulu caranya adalah dengan membunuh diri sendiri, sedangkan taubat umat Islam dengan cara meninggalkan perbuatan dosa, berazam untuk tidak mengulangi lagi dan menyesalinya.

c. Hadis Nabi SAW yang bermaksud: "Sekiranya aku tidak memberatkan orang-orang beriman, pasti aku akan perintabkan mereka bersiwak menjelang shalat". Dalam redaksi yang lain: "...akan memberatkan umatku" (al-Nawawi, t.t.: III: 143). Shah Waliyyullah al-Dahlawi (t.t.: 183) menyatakan bahawa makna dari hadis ini adalah sekiranya tidak memberatkan dan menyusahkan, pasti siwak menjadi syarat sah shalat seperti wudhu. Banyak hadis yang semakna dengan itu. Semua ini membuktikan bahawa ijtihad Rasulullah SAW mempunyai peran penting dalam menetapkan beberapa aturan penting (syari'at). Sabda Rasulullah SAW ini 
berhubungan dengan maqasid al-shariah yang salah satunya adalah meniadakan kesulitan.

Di antara contoh hukum fiqh yang masuk dalam kaedah ini adalah (1) tayammum ketika tiada atau kesulitan menggunakan air, (2) duduk dalam shalat ketika tidak mampu berdiri, (3) mengqasar (memperpendek) dan menjamak (menyatukan shalat dalam satu waktu), (4) 'uzur shalat jum'at dan shalat berjama'ah, (5) menyegerakan zakat, dan lain-lain (al-Suyuti, t.t.: 55; Ibn Najim, t.t.: 83).

Selanjutnya A. Ilyas Ismail (2015) menyoroti tentang keberadaan kemudahan ini, meskipun mudah dan disediakan banyak kemudahan, namun kemudahan itu bukan sesuatu yang dianggap percuma (free of charge). Kemudahan-kemudahan itu menuntut persyaratan dan kondisi-kondisinya sendiri, misalnya:

a. Adanya kesulitan (mashaqqah).

b. Persyaratan lain ialah kemudahan (alternatif) yang disediakan bukanlah dosa atau perkara yang dilarang.

c. Berbagai kemudahan agama itu diberikan oleh Allah SWT untuk maksud dan tujuan yang mulia. Di antara tujuannya: pertama, memastikan agar manusia dapat menjalankan agama tanpa susah payah dalam dimensi ruang dan waktu. Kedua, mendorong dan memotivasi manusia agar rajin dan semangat menjalankan agama, karena agama boleh dilakukan dengan mudah dan tanpa kesulitan.

Adapun kesulitan (mashaqqah) yang dapat mendatangkan kemudahan, maka para ulama berselisih pendapat: 
Pertama: al-Suyuti (t.t.: 55-56) berpendapat ada tujuh, yaitu: (1) safar. Keringanan sebab ini seperti: dibolehkannya shalat qasar dan berbuka puasa. (2) sakit (al-marad), contoh keringanannya: boleh mengguna tayammum karena anggota wudhu tak boleh tersentuh air, shalat fardhu dengan duduk dan shalat jama'. (3) ada unsur paksaan (alikrah). (4) lupa (al-nisyan). (5) kebodohon (al-jab). (6) kesusahan (al-'usr) dan darurat ('umum al-balwa) seperti shalat dengan pakaian atau badan yang ada darah nyamuk atau kutu.

Kedua: Ibn Najim (t.t.: 83) hampir sama dengan al-Suyuti yaitu nomor 1 sampai 6, namun ada tambahan (7) ada kekurangan, contoh kanak-kanak dan orang gila termasuk mereka yang mendapatkan hukum ruksah. Urusan yang berkaitan dengan harta mereka berdua dipercayakan kepadanya walinya.

Ketiga: 'Izzuddin bin 'Abd al-Salam (t.t.: II: 9-10) berpandangan ada enam, yaitu: (1) keringanan dengan cara menggugurkan kewajiban (takhfif isqat), seperti 'uzur yang boleh menggugurkan kewajiban shalat juma'at, haji, umrah dan jihad. (2) keringanan dengan cara mengurangkan kewajiban (takhfif tanqis), seperti menqasar shalat. (3) keringanan dengan cara mengganti (takhfif ibdal), seperti mengganti wudhu dan mandi besar dengan tayammum. (4) keringanan dengan cara mendahulukan (takhfif taqdim), seperti menjamak taqdimkan shalat dan menyegerakan zakat. (5) keringanan dengan cara mengakhirkan (takhfif ta'khir), seperti menjamak ta'khirkan shalat dan menunda puasa bagi yang sakit. (6) keringanan dengan cara memberi keringanan (takhfif tarkhis), seperti memakan najis untuk berobat. Sementara al-'Ala’i (t.t.: 353) menambahkan keringanan yang ke (7) keringanan dengan mengadakan perubahan (takhfif taghyir) seperti perubahan cara shalat pada masa perang. Ya'qub al-Bahsin 
(2005: 196) menambahkan keringanan ke (8) yaitu keringanan dengan memberikan pilihan (takhfif takhyir) seperti diberikan pilihan dalam kaffarah al-yamin antara memberi makan, pakaian atau memerdekakan seorang jiwa.

Dalam penentuan dan pelaksanaan kemudahan-kemudahan dalam Islam (al-taysir al-fiqhi) hendaklah menurut syarat dan kriteria. Menurut Qutb Al-Raysuni (2007), ada batasan atau standard (dawabit) khusus untuk memagari agar penggunaan kemudahan (taysir) tidak disalah gunakan sesuka hati menurut hawa nafsu, tetapi hendaklah berdasarkan ilmu. Di antara yang perlu diwaspadai dalam mengambil kemudahan dalam hukum Islam:

1. Menjaga kawasan yang dimaafkan (al-'afw) dan yang didiamkan (al-maskut 'anb).

2. Mempersempit ruang hukum wajib dan haram.

3. Sederhana dalam mengamalkan dalil berhati-hati (ikhtiyat).

4. Menjauhi perkara yang bid'ah.

5. Mengambil perkara yang paling terpencil (aqallu ma qið).

6. Mengambil pandangan yang paling ringan (al-akbaf).

7. Menggunakan hukum rukhsah pada tempatnya.

8. Membedakan antara maqasid dan wasilah.

9. Membedakan antara wasilah dan bid'ah.

10. Membedakan antara siasat (al-hiyal) dan solusi (al-makharij).

11. Menjaga 'urf.

12. Menjaga maqasid.

13. Menjaga kesan jangka panjang (ma'alat). 
14. Menjaga masalah yang diperselisihkan (khilaf)

15. Melaksanakan figh al-muwazanah.

16. Membuang ta'assub mazhab.

Sementara menurut Nashwan 'Abduh Khalid al-Mikhlafi (2011: 139-40), penerapan taisir harus menurut kriteria seperti berikut:

1. Penyebab taisir betul-betul terjadi atau besar kemungkinannya terjadi, bukan dugaan dan andaian.

2. Taisir itu tidak menghilangkan pokok-pokok agama atau maslahah yang lebih besar.

3. Jika adanya taisir itu untuk menghilangkan mashaqqah sampingan, maka dilakukan sekedar menghilangkan mashaqqah itu tidak boleh melampaui lebih dari pada yang dituntut.

4. Taisir yang diperuntukkan untuk menarik maslabah mursalah hendaknya tidak bertembung dengan nas karena kemaslahatan itu hakikatnya ada pada nas.

5. Sebab mengambil taisir bukan karena menurut hawa nafsu dan menjadikan realitas sebagai dalil untuk membolehkannya atas nama fleksibelitas Islam dan perkembangan zaman.

6. Adanya taisir itu tidak menimbulkan perampasan terhadap hak orang lain.

\section{Maqasid al-Syari'ah}

Menurut pandangan Hasbi al-Siddiqei (dalam Fuad, 2005: 201-2), upaya memecahkan masalah hukum Islam tidak cukup hanya bertumpu kepada metode Qiyas semata-mata seperti mana dipakai secara meluas dalam mazhab Syafi'i. 
Tindakan ini bakal menyebabkan hukum Islam tidak mampu memenuhi tuntutan perubahan zaman, bahkan seandainya metode Qiyas ini dipaksakan pemakaiannya dalam kontek zaman modern, ianya bakal menyebabkan banyak kemaslahatan manusia akan terabai. Atas dasar inilah, beliau menekankan peri pentingnya penetapan kaedah penetapan hukum yang berbasiskan konsep maqasid al-shariah.

Menurut al-Gazali (1993: 287) maqasid al-shari'ah merujuk kepada tujuan syara' terhadap manusia yaitu penjagaan terhadap lima perkara yaitu agama, jiwa, akal, keturunan dan harta. Al-Amidi (1980: 296) pula mendefinisikan maqasid al-shariah sebagai tujuan dari pensyari'atan hukum sama ada untuk mencapai kemaslahatan atau menolak kemudaratan atau kedua-duanya sekali. Senada dengan ta'rif al-Amidi, 'Iz alDin bin 'Abd al-Salam (1962: 9) juga mendefinisikan maqasid al-shari'ah sebagai maslahat sama ada ia menolak kerusakan atau mencapai kebaikan.

Sementara menurut al-Shatibi (t.t.: 235), maqasid al-shari'ah adalah pentaklifan syara' yang bertujuan memelihara maksudnya terhadap manusia. Selanjutnya menurut Ibn al-Qayyim (1996: 37), apa-apa yang disyari'atkan oleh Allah s.w.t adalah berasaskan kepada hikmah-hikmah dan maslahah-maslahah untuk manusia sama ada di dunia atau di akhirat. Maka apa-apa perubahan hukum yang berlaku berdasarkan perubahan masa dan tempat adalah untuk memelihara maqasid di sebalik syari'at Islam demi mencapai kemaslahatan bagi manusia.

Adapun Ibn 'Ashur (1998: 171) membagikan maqasid kepada dua bagian: Pertama: maqasid 'ammah, yaitu: pengertian yang mendalam dan hikmah yang diletakkan oleh pembuat syari'at disebalik semua ataupun kebanyakan perundangan syari'ah. Kedua: 
maqasid khassah adalah metode-metode yang digunakan oleh al-shariuntuk merealisasikan objektif manusia yang bermanfaat atau untuk memelihara kepentingan umum mereka dalam urusan personal mereka.

Ilal al-Fasi (2013: 111) pula menjelaskan maqasid al-shariah sebagai tujuan daripada syari'ah, serta rahasia-rahasia yang diletakkan oleh pembuat syari'at bagi keseluruhan hukum-hukumnya. Adapun al-Raysuni (1997: 7) menyatakan bahwa maqasid merupakan tujuan yang ingin dicapai dalam melakukan sesuatu dan dalam kontek maqasid al-shari'ah, ia bermaksud objektif yang diletakkan oleh syarak dalam mensyari'atkan sesuatu hukum. Manakala menurut Jasser Awda (2014: 4) maqasid alshariah ialah himpunan tujuan-tujuan ketuhanan dan konsep-konsep moral yang mendasari undang-undang Islam seperti keadilan, kemuliaan, kesucian dan kemudahan.

Wahbah al-Zuhaili (2005: 1017) mendefinisikan maqasid al-shari'ah sebagai makna-makna dan tujuan yang dititikberatkan dalam semua hukum atau sebahagian besarnya atau matlamat dari syari'ah dan rahasia-rahasia yang diletakkan oleh al-shari' dalam setiap hukum.

Adapun pandangan Yusuf al-Qaradawi (Dirasah, 20-1) tentang maqasid al-shariah adalah tujuan-tujuan yang menjadi objektif bagi nas-nas syara' yang meliputi aspek perintah, larangan dan keharusan, yang mana hukum-hukum syara' yang bersifat ju₹, $i$ berperan untuk merealisasikannya dalam kehidupan sama ada individu, keluarga, masyarakat dan ummah. Maksud-maksud ini juga boleh diartikan sebagai hikmah- 
hikmah yang menjadi tujuan ditetapkan hukum yang dishari'atkan oleh Allah kepada hamba-Nya.

Secara umum, maksud daripada maqasid al-shariah tidak ada perbedaan yang ketara diantara definisi-definisi yang telah disebutkan oleh para Ulama baik klasik maupun Sarjana Kontemporer. Allah SWT menurunkan syari'ah untuk tujuan kemaslahatan dan kesejahteraan manusia. Semua aturan syari'ah mempunyai maqasid yang ingin dicapai (Abubakar, 2016: 52-3). Dengan demikian, dapat disimpulkan bahawa perbincangan maqasid turut dikaitkan dengan maslahah, karena objektif syari'ah itu sendiri adalah untuk jalb al-masalih wa dar' al-mafasid.

Dari pengertian di atas, al-Qaradawi memberikan contoh dalam bab rukbsah diperbolehkan berbuka puasa, shalat jamak dan qasar bagi seorang musafir. Dalam hal ini para Usuliyyin berpendapat bahawa safar itulah yang menjadi 'illat (sebab) diberlakukannya hukum rukhsah berbuka puasa, shalat jamak dan qasar bukan mashaqqah (kepenatan) dalam perjalanan. Adapun mashaqqah dalam safar itulah yang termasuk dalam kategori maqasid atau hikmah di sebalik hukum rukhsah dalam puasa dan shalat itu. Selain contoh di atas masih banyak lagi contoh-contoh lain yang menjelaskan tentang kedudukan maqasid berbanding 'illat suatu hukum yang sudah dijelaskan secara luas oleh Usuliyyin (al-Qaradawi, Dirasah, h. 21).

Adapun kepentingan memahami maqasid al-shariah secara umum adalah untuk memahami bahawa maqasid al-shariah merupakan roh kepada setiap perbuatan. Hukum fiqh tanpa maqasid al-shariah seolah hukum tanpa roh dan pendakwah yang 
tidak memahami dan menguasai maqasid maka mereka termasuk golongan yang tidak mempunyai roh pendakwah sebenar.

Namun secara terperinci, Nuruddin Mukhtar al-Khadimi menyenaraikan kepentingan mempelajari ilmu maqasid al-shari'ah seperti berikut:

a. Mengetahui sebab atau alasan dan hikmah dishari'atkannya sesuatu hukum.

b. menambahkan pengetahuan penyelidik terhadap hubungan maqasid dengan kaedah-kaedah usul yang lain seperti hubungan maqasid dengan maslahah, qiyas dan lain-lain.

c. Mengurangkan perbedaan pendapat fiqh dan ta'asub mazhab.

d. Menolong seorang Muslim untuk melakukan ketaatan kepada Allah dengan sempurna.

e. Menolong para pendakwah dan orang yang berpartisipasi dengan Islam agar menunaikan tugas mereka bertepatan dengan syari'at Islam dan konsep amar makruf dan nahi munkar. Ia bukan berdasarkan kepada kefahaman literal dan maksud lahirnya saja (al-Khadimi, 1421: 51).

Selanjutnya, menurut al-Qaradawi terdapat tiga aliran dalam kaitanya dengan pemahaman dan penggunaan maqasid al-Shariah dan nas: Pertama: aliran yang bergantung kepada teks atau nas semata, memahaminya dengan pemahaman literal (harfiah) dan jauh dari maksud syariat yang ada di sebaliknya. Mereka adalah golongan literal yang disebut sebagai Neo Zabiriyah yang mewarisi zabiriyyah zaman silam yang mengingkari adanya ta'lil dalam hukum, menghubungkannya dengan hikmah dan maksud dan juga qiyas. Kedua: aliran yang mengakui bahwa mereka lebih bergantung 
kepada maqasid al-Shariah dan roh agama dengan menggugurkan nas-nas dalam alQuran dan al-Sunah walaupun nas itu jelas dan qat'i. Golongan ini menakwilkan alQuran secara berlebihan, memegang ayat mutashabihat dan meninggalkan yang mubkamat. Mereka adalah orang yang menyeru ke arah pembaharuan. Padahal dalam kenyataannya mereka adalah penyeru kepada pembaratan dan kerosakan. Mereka adalah Golongan Neo Mu'tazilah atau Kumpulan Liberal pada masa ini. Ketiga: aliran sederhana dan moderat yang tidak melupakan teks-teks al-Quran dan al-sunah dan dalam waktu yang sama tidak memisahkanya dari maksud maksud yang global (maqasid al-shariah). Bahkan teks teks tersebut difahami dalam kerangka maksudmaksud yang global. Aliran inilah yang diyakini untuk dijadikan sebagai manhaj bagi menjelaskan gambaran yang sebenar hakikat Islam, membantah kebatilan orang yang memusuhinya dan berbaik sangka kepada Allah dan rasul-Nya (al-Qaradawi, Dirasah, $39-41)$.

Dalam perkembangannya, ilmu maqasid selepas zaman al-Shatibi dilihat mengalami sedikit gangguan seakan tergendala seketika. Hal ini dapat dilihat melalui karya agung beliau yaitu al-Muwafaqat yang mula berhenti dikaji dan dirujuk oleh para sarjana lain ratusan tahun lamanya sehingga diangkat dan dipopularkan semula oleh tokoh gerakan islah dan tajdid yaitu Muhammad 'Abduh pada penghujung abad ke- 19 masehi untuk kembali dikaji dan dirujuk terutamanya dalam kalangan mahasiswa Universiti al-Azhar (Childs, 2016: 11).

Secara umumnya, disiplin ilmu maqasid berkembang dari masa ke semasa dengan kelahiran tokoh-tokoh yang baru yang mengembangkan lagi maqasid-al shari'ah. Selain dari itu perubahan zaman yamg cukup drastis juga menuntut kepada solusi dalam 
menyelesaikan segala persoalan yang datang. Salah seorang tokoh yang merintis pengembangan maqasid adalah Ibn 'Ashur. Beliau telah membuka pintu kebuntuhan kepada para Sarjana Muslim Kontemporer bagi mengembangkan teori maqasid menerusi cara baru. Orientasi pandangan-pandangan baru itu bukan teori muzajir alAmiri ataupun teori hifz al-Gazali, tetapi sebaliknya dengan mendatangkan konsepkonsep nilai dan sistem. Konsep-konsep baru yang dicadangkannya adalah konsep keadilan, kebebasan, fitrah dan persamaan.

Sementara itu, Taha Jabir al-'Alwani juga memberikan kontribusi besar dalam pemikiran maqasid al-shariah yaitu dengan hasil penalaran induktifnya yang sempurna terhadap al-Qur'an dengan menyimpulkan bahawa terdapat tiga maqasid tertinggi bagi al-Qur'an (al-Maqasid al-Qur'aniyyah al-Ulya al-Hakimah) yaitu: al-tawhid, al-tazkiyah dan al-umran. Ketiga-tiga maqasid ini menjadi rujukan utama dan pemutus setiap isu. Malahan menurutnya, maqasid ini menjadi rujukan dalam melakukan kritikan terhadap turat (IDE Research, 2017: 92).

Selanjutnya, Jasser Awda membincangkan maqasid al-shari'ah dari perspektif yang baru lagi, yaitu berdasarkan pendekatan sistem (Awda, 2014: 24). Beliau melakukan reformasi yang dulunya bernuansa penjagaan (protection) dan pelestarian (preservetion) menuju maqasid yang bercitarasa pengembangan (development) dan keutamaan hak asasi (buman right) yang perlu dijadikan tema dalam penentuan hukum Islam semasa (Abdullah, 2014: 11). Hal ini karena dilihat klasifikasi maqasid klasik hanya bertumpu kepada maqasid individu semata berbanding masyarakat secara umum (penjagaan asas yang lima). 
Namun begitu, maqasid yang bersendikan parameternya al-daruriyyat, apakah hanya terbatas pada yang lima aspek sahaja? Atau masih bias dikembangkan lagi? Dalam perbincangan para ulama, ada yang menambahkan daruriyyat keenam yaitu menjaga kehormatan, ada juga yang menambah sampai delapan yaitu al-Nabhani (alKamali, 2000: 129-33). Bahkan bagi 'Abd al-Latif al-Humayyin menambahkan sehihgga sepuluh (usul al-'asharah), yaitu agama, akal, nyawa, jasad, harta, nasab (keturunan), nasal (usia), al-zawj (pasangan), al-ird (kehormatan) dan al-watan (tanah air). Usul ini berdasarkan penelitian beliau terhadap nass al-Qur'an, Hadis dan Ijmak (al-Humayyin, 2004: 39-40). Para pengkaji dari Universiti Malaya menambahkan dalam kontek semasa, penjagaan alam sekitar (bifz al-bi'ah) juga relevan untuk dimasukkan dalam kategori al-daruriyyat. Ini karena pengabaian penjagaan ini bisa mengancam nyawa manusia (Ramli, 2016: 130).

Selanjutnya, al-Qaradawi menganjurkan untuk mengambil pandangan ulama kontemporer yang giat membicarakan tentang maqasid seperti Rasyid Rida dalam kitabnya yang masyhur "Al-Waby al-Muhammad" berbeda dalam membahas maqasid dengan para ulama maqasidi sebelumnya. Menurutnya dalam penentuan maqasid tidak menggunakan metode asas maslahah yang terangkum dalam tiga tingkatan: aldaruriyyat, al-hajizyat dan al-tabsiniyyat, tetapi dengan berinteraksi langsung dengan topik-topik yang dibincangkan dalam Islam. Topik-topik inilah yang menjadi maqasid al-kubra (al-Qaradawi, Dirasah, 25).

Di antara perbincangan Maqasid selanjutnya yang dicadangkan oleh alQaradawi merujuk kepada jenis maqasid utama yang diasaskan oleh al-Gazali adalah penambahan maqasid yang skopnya lebih luas dari sekadar membincangkan maqasid 
yang objeknya individu menjadi maqasid yang objek utamanya adalah kemasyarakatan (sosial), maka beliau mengusulkan maqasid atau masalih daruriyyah yang lain yaitu:

a. Yang berkaitan dengan nilai-nilai kemasyarakatan (al-qiyam al-ijtima'iyyah) seperti kebebasan (al-burriyyah), persamaan (al-musawat), persaudaraan (al-ikha), kebersamaan (al-takaful) dan hak asasi manusia (buquq al-insan) (al-Qaradawi, Dirasah, 28).

b. Apa-apa yang berkaiatan dengan pembinaan masyarakat, bangsa dan negara (takwin al-mujtama' wa al-ummah wa al-dawlab). Menurut al-Qaradawi, para Usuliyyin dahulu tertuju hanya kepada maqasid yang berpaksikan kemaslahatan individu baik dari sisi agama, jiwa, keturunan, akal dan hartanya tidak menyentuh kepada persoalan-persoalan yang ruang lingkupnya sosial kemasyarakatan, urusan bangsa dan negara serta hubungan internasional dengan negara-negara di dunia yang bersifat global dan semasa. Atas dasar ini maka beliau mencadangkan semua jenis maqasid di atas (al-Qaradawi, Dirasah, 28).

c. Yang berkaitan dengan akhlak yang utama, seperti sifat: jujur (sidq), amanah (amanab), adil ('adb), baik (ibsan), menjaga diri ('iffah), malu (baya), rendah diri (tawadu'), harga diri ('izzah), kasih sayang (rahmah), lembut (rifq), berani (shaja'ab) dan pemurah (sakha) (al-Qaradawi, Dirasah, 29).

d. Al-Qaradawi juga mengusulkan maqasid berdasarkan perluasan makna dari pada al-kulliyyat al-khams yang diusung oleh al-Gazali agar penafsiran al-kulliyyat itu diperluaskan pembahasannya sampai menghasilkan hukum yang boleh menyelesaikan banyak masalah kontemporari hari ini. Sebagai contoh: penjagaan akal (bifž al-'aql) yang menghasilkan hukum diharamkannya khamr (penafsiran 
penjagaan atau pemeliharaan) menjadi penafsiran yang sifatnya menambah baik dan mengembangkan fungsi akal seperti kewajiban mencari ilmu, rihlah untuk mencari ilmu, belajar sepanjang hayat, mengejar ilmu-ilmu yang diperlukan saat ini sebagai sarana untuk melengkapi keperluan hidupnya baik urusan dunia maupun urusan akhirat (fardhu kifayah), membuat program-program atau seminar untuk meningkatkan pemikiran yang membangun umah dan mengikis pemikiran konservatif taqlid yang membawa umat jadi mundur seperti yang terjadi pada generasi nenek moyang kita dahulu dan lain-lain agenda yang membawa umat ke hadapan dari sisi ilmu pengetahuan. Demikian juga pada kulliyyat-kulliyat yang lain (al-Qaradawi, Dirasah, 29-30).

\section{METODE}

Penulisan ini menggunakan metode survey kepustakaan yang kemudian diinterpretasikan dengan teori hukum Islam. Dari segi kemasyarakatan, Islam mempunyai teori tersendiri untuk mengatur masalah kemaslahatan umat. Untuk mengilustrasikan mengapa sikap memudahkan itu penting bagi kehidupan bermasyarakat, kami mencatat bahwa hipotesis kontemporer yang paling menonjol dalam literatur tentang agama dan moralitas adalah hipotesis "prososialitas agama". Meskipun banyak makalah tentang "prososialitas agama" tampaknya menyamakan pengertian moralitas dan "prososialitas" (misalnya, Norenzayan \& Shariff, 2008), beberapa menyiratkan bahwa moralitas adalah subkategori dari prosociality (eg, Galen, 2012), sedangkan yang lain menunjukkan bahwa prosociality adalah subkategori moralitas (misalnya, Preston, Salomon, \& Ritter, 2014). Namun, dalam semua kasus 
ini, prososialitas digunakan untuk menunjukkan perilaku sukarela yang secara sengaja menguntungkan orang lain dengan biaya pribadi (misalnya, membantu, menghibur, berbagi, menyumbang, menjadi sukarelawan) —dengan kata lain, perilaku "baik" (meskipun ada motivasi untuk terlibat dalam perilaku mungkin murni egois; Saroglou, 2013). Meskipun penggunaan ini mencerminkan bahasa populer dan tradisi ilmiah sosial yang terhormat (Batson \& Powell, 2003), namun nampaknya sangat membingungkan. Oleh karena itu, kajian teks asli dari pakar yang mumpuni di bidang keislaman seperti Yusuf al-Qaradawi sangatlah penting dalam pembangunan fondasi hukum pada masyarakat Islam.

\section{HASIL DAN PEMBAHASAN}

Setelah menguraikan konsep fiqh al-taisir dan konsep maqasid al-shariah, maka didapati antara keduanya ada hubungan yang sangat erat, karena yang dijadikan formula atau premis dalam fiqh al-taisir baik versi al-Qaradawi maupun konsep taysir hukum Islam pada umumnya merupakan bagian dari pada maqasid al-shari'ah, namun dalam artikel yang singkat ini hanya menganalisis fiqh al-taisir versi al-Qaradawi saja. Ada beberapa isu yang dikaji dalam fiqh al-taisir al-Qaradawi, di antaranya:

\section{a. Maksud fiqh al-taysir}

Adapun yang dimaksud dengan fiqh al-taisir menurut al-Qaradawi adalah: mempermudah kefahaman bagi seorang muslim kini yang sibuk dengan urusan kehidupan yang dipenuhi dengan ledakan maklumat dan ilmu pengetahuan. Disamping itu juga mempermudah hukum-hukumnya agar mudah dilaksanakan dan diamalkan sambil menghindari sikap memberatkan dan menyusahkan serta memilih pendapat yang ringan dan mudah (al-Qaradawi, 1999: 15). 
Berdasarkan pengertian ini, al-Qaradawi menjelaskan tentang maksud dari pada fiqh al-taisir berikut dengan skopnya. Artinya, pandangan beliau ini sudah melebar dan meluas dari pada pandangan ulama-ulama sebelumnya, karena, al-Qaradawi menggiring opini kita dalam memahami fiqh al-taisir dengan memasukan prinsip taysir dalam pemahaman Islam berbanding dengan pandangan para ulama sebelumnya (dalam memahami fiqh al-taisir) yang hanya menggunakan taisir dalam pelaksanaan hukum Islam.

Al-Qaradawi meyakini bahwa manhaj kemudahan (fiqh al-taisir) ini merupakan manhaj Islam itu sendiri. Menurutnya, syariat Islam itu sendiri dibangunkan atas kemudahan dan menghapuskan kesulitan-kesulitan dalam ibadah. Disamping itu pada zaman sekarang ancaman pemikiran dan kebejatan moral begitu tinggi yang memerlukan pendekatan yang mudah baik dalam pemahaman maupun dalam pelaksanaan.

Penulis menilai bahwa pandangan al-Qaradawi ini sah-sah saja bahkan diperlukan karena hal ini akan menambah pengetahuan bagi para peneliti dan pengkaji hukum Islam saat ini tentang pemahaman fiqh al-taisir, karena dengan pemahaman ini kita akan lebih bersedia untuk menjawab segala persoalan terkini berdasarkan fiqh al-taisir. Namun disisi lain perlu diperhatikan konsep taysir ini agar tetap dalam prinsip yang digariskan oleh syari’at (metodologi ulama usul fiqh).

\section{b. Dasar Pemikiran fiqh al-taysir}

Ajakan kepada Islam berdiri atas landasan memberi khabar gembira bukan memberi ketakutan. Al-Qaradawi berbujjah dengan al-Qur'an dan Hadis yang 
menggambarkan syari'at Islam ditegakan atas dasar kemudahan seperti firman Allah yang bermaksud: "Allah menghendaki kamu beroleh kemudahan, dan ia tidak menghendaki kamu menanggung kesukaran." (Surah al-Baqarah, 2: 185).

Pemikiran ini mengambil sikap pendekatan mudah untuk manusia. Ini tidak berarti aliran ini menyeleweng dari teks untuk mencari yang paling mudah bagi manusia. Aliran ini meneliti teks dan meningkatkan pemahaman agar menemukan kemudahan agama yang diinginkan oleh Allah SWT. Ini didasarkan kepada pemahaman hadis bahwa: jika ada dua perkara, satu perkara yang mudah dan satu lagi yang sulit, maka aliran ini akan memilih yang mudah (al-Qaradawi, Dirasah, 151).

Konsep taisir dalam hukum Islam sebenarnya telah digagas oleh para ulama usul dan ulama qawa'id al-fiqbiyyah seperti yang telah dijjelaskan sebelum ini. Namun konsep dan pelaksanaannya agak berbeda dengan konsep yang ditawarkan oleh alQaradawi. Perbincangan fiqh al-taisir versi ulama usul hanya terfokus dalam bab taysir dalam hukum Islam dengan beragam kaedah yang disusunnya, namun fiqh al-taisir versi al-Qaradawi meliputi konsep taisir, sarana ilmu pengetahuan, pemahaman dan pelaksanaannya yang luas. Sehingga terkadang pemikiran al-Qaradawi terkesan seolah-olah suka memudahkan hukum Islam, bahkan ada yang menganggapnya seolah-olah sudah sesat dan sebagainya, padahal jika dikaji lebih dalam fiqh al-taisir yang digagas oleh al-Qaradawi ini tetap dalam koridor yang dibenarkan dalam hukum Islam. 


\section{c. Formula Fiqh al-Taisir al-Qaradawi}

Menurut al-Qaradawi, fiqh al-taisir meliputi dua sisi yang perlu diperhatikan yaitu sisi pemahaman dan sisi pelaksanaan. Di bawah ini adalah uraian dengan terperinci

\section{Pertama: sisi pemahaman}

1. Penyatuan antara kemudahan dan kesederhanaan.

Al-Qaradawi menyarankan agar figh itu ditulis dengan bahasa yang sederhana, menggunakan perkataan yang mudah difahami, tidak berat dan susah atau menggunakan ungkapan-ungkapan yang dibuat-buat. Jika terpaksa menggunakan bahasa yang susah difahami maka hendaknya diterjemahkan ke dalam bahasa yang mudah difahami oleh pembaca. Seharusnya bahasa yang digunakan berada diantara yang sangat ringkas dan sangat panjang. Sebab jika terlalu pendek maka tidak akan memberi gambaran yang jelas dan sebaliknya jika terlalu panjang maka akan membosankan para pembaca (al-Qaradawi, Dirasah, 16).

Pandangan al-Qaradawi ini tepat mengingat realitas yang ada kita mendapati ada sebahagian kitab-kitab fiqh yang menguraikan perbincangan sesuatu topik dalam hukum Islam dengan pembahasan yang terlalu luas dan terkadang menggunakan bahasa yang tinggi dan susah sehingga sedikit banyak akan menyusahkan para pembaca. Maka dengan cetusan ide ini diharapkan dapat mengurangi kesukaran dan mempercepat pemahaman umat Islam terhadap hukum Islam. Penulis menilai ide ini berita baik bagi umat Islam terutama untuk para sarjana hukum Islam hari ini. Adapun kitab-kitab fiqh yang telah ada (baik yang menggunakan bahasa yang mudah 
dan sederhana maupun yang klasik) sebagai khazanah turath al-islam yang patut kita jaga dan dijadikan sebagai rujukan.

2. Kemampuan berkomunikasi dengan cara berfikir orang modern.

Perbahasan yang ada di dalam fiqh itu boleh dikomunikasikan dengan akal orang modern dengan bahasa yang beredar di kalangan mereka (QS. 14: 4). Bahasa yang dimaksud di sini adalah hendaknya seseorang faham cara berfikir yang digunakan oleh orang awam dan bahasa yang digunakan oleh orang khusus. Setiap mereka mempunyai bahasa dan akal tersendiri. Demikianlah cara berfikir dan akal manusia di zaman ini berbeda dengan manusia di zaman dahulu (al-Qaradawi, Taysir, 16-7).

3. Menggunakan pengetahuan modern, standard dan istilah-istilahnya

Pengetahuan modern yang dimaksud adalah pengetahuan modern dalam rangka untuk menerangkan hukum syari'ah atau dalam menguatkan sebahagian pendapat dalam fiqh, atau dalam menerangkan hikmah dalam syari'ah baik yang wajib, sunnah, makruh maupun yang mubah (al-Qaradawi, Taysir, 17).

4. Menghubungkan fiqh dengan realitas dan membuang yang tidak berhubungan

Diperlukan untuk menghubungkan fiqh dengan realitas dan membuang yang tidak perlu dan tidak menjadi perbincangan umum seperti masalah perhambaan, dimana masalah ini menjadi masalah yang tidak relevan lagi dibahas saat ini.

5. Menerangkan hikmah disyari'atkanya suatu hukum

Hal ini sangat penting dilakukan agar masalah fiqh mudah difahami. Ini ditujukan agar akal manusia menjadi puas dan hati menjadi tenang. Sebab Allah tidak 
mensyari'atkan sesuatu kecuali didalamnya akan selalu terkandung hikmah. Sebagaimana Allah juga bebas dari tindakan batil dalam ciptaan-Nya dan dia juga maha suci dari kesia-sian dalam penetapan syari'ah-Nya.

6. Menghubungkan antara satu hukum dengan hukum yang lain.

Menghubungkan antara hukum-hukum yang bersifat juz’i dengan maksud syari'ah yang bersifat kulli dan yang umum dalam syari'ah, sebab Islam adalah agama yang tidak mengenal pemisahan. Sebagai contoh ketika Islam membicarakan tentang diyat (tebusan darah) terhadap seseorang yang membunuh secara tidak sengaja, maka dia juga harus membincangkan berkenaan nafkah dalam Islam diantara kaum kerabat, dan hendaknya dia juga membicarakan hukum waris sehingga masalah menjadi jelas dan berada dalam gambaran yang kulli dan menyeluruh, dan terlihat mana pihak yang diuntungkan dan dirugikan. Dengan demikian, maka akan ada hubungan dan ikatan antara satu hukum dengan hukum yang lain (al-Qaradawi, Taysir, 21).

7. Meringankan tambahan dalam ibadah

Hendaknya pembahasan dalam fiqh itu tidak disertai dengan banyaknya tambahan dan cabang-cabang serta hal-hal yang remeh temeh yang merupakan hasil dari peredaran zaman (khususnya dalam masalah ibadah) sehingga akan mengandungi banyak perincian yang mengubah ajaran agama dari mudah menjadi susah. Isam Talimah menuturkan, "Saya masih ingat -waktu itu saya masih kecil- ketika saya mendengar pelajaran agama di bulan Ramadan dari lepas maghrib sampai isya sebulan penuh. Apa yang kami pelajari sebulan penuh itu belum mampu menghabiskan masalah wudu dan bersuci. Hingga dengan sedikit bergurau saya 
katakan: "Sesungguhnya dalam sebulan ini kita tidak keluar dari bilik mandi”. Padahal kalau kita mengkaji balik zaman Nabi maka kita dapati pemahaman fiqh cukup mudah. Dikisahkan pada masa Rasulullah SAW ada seorang lelaki yang berasal dari dusun datang menemui Rasulullah SAW. Dia belajar wudhu dan shalat dengan cara melihat bagaimana cara dia berwudhu dan shalat beberapa kali. Saat itu Rasulullah bersabda: "Shalatlah kamu sebagaimana kamu melihat aku shalat" (HR. Bukhari). Rasulullah SAW memberikan nasihat-nasihat dan arahan kepadanya. Setelah itu dia pulang menemui kaumnya dan faham benar mengenai agamanya. Dia pulang untuk mengajarkan agama yang dia fahami itu kepada kaumnya (al-Qaradawi, Taysir, 21).

8. Mengambil faedah dari tulisan-tulisan masa kini

Yang dimaksud dengan tulisan-tulisan masa kini adalah tulisan-tulisan ulama yang boleh dipercaya yang menulis bidang fiqh, khususnya dalam buku-buku fiqh perbandingan serta dari keputusan institusi fiqh yang berada di seluruh dunia. Kita juga patut mengambil tesis master dan disertasi doktor falsafah (PhD) di universisitiuniversiti yang membahaskan masalah fiqh. Di samping juga dari ensiklopedia Islam yang terbit di Kuwait dan Kaherah serta dari kajian dan fatwa yang dikeluarkan oleh institusi khusus yang bidang fatwa. Demikian juga dari fatwa-fatwa yang datang dari penasihat syari'ah di bank-bank Islam (al-Qaradawi, Taysir, 22).

9. Klasifikasi buku-buku

Al-Qaradawi menyarankan akan lebih baik jika buku-buku fiqh itu dipelbagaikan bukan hanya satu jenis sahaja. Hendaknya buku-buku fiqh itu ditujukan menurut citarasa cerdik pandai terkini sehingga mudah difahami oleh seorang muslim dengan 
baik dan tepat. Dengan cara misalnya memulainya dari masalah-masalah yang sangat penting dan akhirnya mencakup semua masalah figh. Mungkin dibagi dibagi dalam dua atau tiga tahap.

10. Pemberian nomor dan simbol-simbol yang lain serta pencantuman indek

Dalam penulisan fiqh hendaknya diberi nomor dan tanda-tanda yang telah disepakati. Dalam penulisan al-Qur'an hendaknya mencantumkan nomor ayat dan nama surah. Untuk hadis hendaknya hadis dalam keadaan berharkat, menyebutkan perawi dan keterangan tentang darjat sesuatu hadis jika hadis tersebut bukan dari hadis sahih Bukhari dan Muslim, serta tidak mendatangkan dalil dari hadis yang darjatnya lebih rendah dari hadis hasan.

Selanjutnya seorang penulis fiqh dituntut untuk menggunakan simbol-simbol yang biasa digunakan dalam era modern untuk mendapatkan pemahaman yang jelas. Sarana-sarana yang digunakan hendaknya baik, halal, sesuai dan memudahkan, yaitu berupa gambar, foto, statistik, jadual dan peta. Penulis juga hendaknya mencantumkan indeks (al-Qaradawi, Taysir, 23).

11. Menggunakan istilah yang ada dalilnya

Setelah menguraikan perincian fiqh al-taisir dalam pemahaman yang dicadangkan oleh al- Qaradawi, penulis berpendapat bahawa figh al-taisir ini pada dasarnya boleh diterima karena ia tidak keluar dari manhaj fiqh para ulama ulama dan pandangannya serta relevan hari ini untuk menjawab isu-isu semasa. Figh al-taisir ini menerangkan pemikiran orang-orang hari ini seperti keupayaan untuk berkomunikasi dengan cara berfikir modern, menggunakan pengetahuan modern, piawaian dan istilah, 
menghubungkan fiqh dengan realitas dan membuang yang tidak berkaitan, menjelaskan kebijaksanaan undang-undang (bikmah al-tashri), menghubungkan antara satu hukum dengan hukum lain, menghilangkan beban tambahan dalam ibadah, mengambil kesempatan daripada tulisan kontemporari, klasifikasi buku dan memberi angka dan cara latihan dan pengindeksan lain. Semua terma ini sangat sesuai dengan pemikiran generasi sekarang dan sesuai dengan tuntutan syari'at (maqasid al-shariah), sehingga menjadikan al-Qaradawi sebagai tokoh ulama semasa yang popular bertaraf dunia.

Namun demikian ada sebahagian kecil klausa yang menimbulkan kontroversi dan melawan arus pemikiran fiqh para ulama yaitu tentang penggunakan istilah yang ada dalilnya. Klausa ini menurut penulis tidak perlu dimasukan dalam kerangka penyusunan fiqh al-taisir, karena penggunakan istilah-istilah fiqh itu bukan perkara yang mendasar dalam fiqh, sebab penggunaan istilah itu tidak signifikan dan bersifat relative. Terkadang penggunaan istilah berbeda antara satu mazhab dengan mazhab yang lain (al-Bakri, 2010: 5-6). Perkara ini sedia maklum dan tidak menimbulkan masalah selama ini.

\section{Kedua: sisi pelaksanaan}

Adapun kemudahan fiqh dalam amalan dan prakteknya dapat direalisasikan oleh al-Qaradawi dengan mengambil pendapat yang mudah ketika memberikan fatwa kepada kaum muslimin. Hal ini diambil karena manusia saat ini memerlukan kemudahan dalam hal fatwa bukan yang menyulitkan, khususnya di zaman ketika manusia dari agamanya memiliki dampak yang tidak kecil di belakangnya. 
Diantaranya adalah bisikan syaitan bagi mereka bahawa apa yang dilakukan adalah dosa yang tidak akan diampuni atau adanya seruan dari orang-orang yang memusuhi agama yang menyifatkan agama ini sebagai agama yang mengekang kebebasan dan tidak memberi peluang serta adanya anggapan bahwa agama selalu melakukan tindakan-tindakan yang tidak sepatutnya.

Oleh itu boleh menyebabkan seseorang lari dari agama itu karena adanya pemahaman yang salah akibat dari orang-orang yang menutup pintu dakwah dan orang-orang yang yang mengeluarkan fatwa. Hal ini terjadi disebabkan mereka mengambil pandangan yang memberatkan walaupun disana ada pendapat-pendapat yang lebih ringan dan mudah. Oleh sebab itu pada zaman ini kita memerlukan seorang yang membuka jalan bagi kemudahan-kemudahan dalam fatwa.

Kemudahan yang dimaksud oleh al-Qaradawi bukanlah mempermudahkan, meremehkan, mengurangkan ataupun tidak memperhatikan dan melanggar perintah Allah serta nas-nas syari'ah. Yang dimaksud kemudahan adalah kecenderungan dalam memberikan fatwa dan pandangan kepada yang lebih mudah bagi orang-orang yang telah mukallaf. Ini berlaku jika masalahnya berada dalam ruang lingkup ijtihad atau ada nas yang masih terbuka dalam penafsiran. Maka yang demikian itu tentu tidak bertentangan dengan syariah, bahkan penafsiran itu merupakan penerapan ruh syari'ah (maqasid al-shariah) sepertimana sikap Rasulullah SAW terhadap seorang arab badwi yang kencing di masjid nabawi di Madinah (al-Qaradawi, Taysir, 26).

Adapun kriteria kemudahan dalam pelaksanaan (tatbiq) yang diusung oleh alQaradawi adalah: 


\section{Memperhatikan sisi keringanan atau rukhsah}

Menjaga sisi kemudahan dan keringanan dalam hukum Islam hendaknya dilakukan dengan tepat dan proporsional seperti yang diterapkan pada hukum 'azimah (keadaan normal). Tiap-tiap hukum diperuntukan untuk pelakunya masingmasing, masa dan kondisinya masing-masing, maka tidak selayaknya memperlakukannya dengan satu kondisi yang sama. Hukum yang diperuntukan bagi orang yang lemah tidak boleh dibebankan sepertimana bagi orang yang mampu, demikian juga bagi orang yang baru masuk Islam (yang masih jauh dari agama) tidak boleh disamakan dengan orang yang sudah menguasai persoalan agama dan yang sudah komitmen dengan Islam (al-Qaradawi, Taysir, 24).

Prinsip taisir yang dipegang oleh al-Qaradawi ini sama dengan prinsip taisir yang dipegang oleh para ulama usul fiqh selama ini, artinya tidak ada yang baru dalam hal ini. Al-Qaradawi meneruskan tradisi yang dibawa oleh para ulama sebelumnya bahkan memperkuat perbincangan taisir dalam hukum Islam. Seperti sedia maklum bahwa di dalam hukum Islam terdapat dua keadaan dalam penerapan dan pelaksanaanya yaitu kondisi normal yang kita kenal dengan istilah hukum 'az̧imah dan kondisi tidak normal dengan sebab-sebab tertentu seperti kondisi sakit, safar, darurat, dan lain-lain seperti yang dibincangkan dalam ilmu usul fiqh dan qa'idah fiqbiyyah. Hukum yang diberlakukan pada kondisi yang kedua ini disebut dengan hukum rukhshah (al-Zuhayli, 2005: 165-86; Zaydan, 2012). Sedangkan dari sisi maqasid alshari'ah pula hukum rukhsah diambil atas dasar memberikan keselesaan kepada manusia dan menghilangkan kesusahan (jalb al-masalih wa dar' al-mafasid). 
2. Memperhatikan keadaan yang mendesak dan keadaan yang meringankan

Pada point ini juga sama dengan yang dibincangkan oleh para ulama usul figh dan disebutkan dalam kaedah fiqh yaitu perbincangan masalah darurat. Kaedah darurat ini luas perbincangannya dan tetap relevan sampai ke hari ini, bahkan alQaradawi mengatakan bahwa manusia saat ini memerlukan pandangan fiqh yang mudah termasuk salah satu kemudahan karena kondisi darurat seperti ini. Jadi memang sudah jelas keadaan darurat ini menghendaki kemudahan baik secara teori maupun fakta seperti yang dituntut dalam agama.

3. Memilih yang paling mudah bukan yang paling berhati-hati di zaman ini

Kata al- Qaradawi: manhaj yang menjadi pilihan saya adalah akan selalu komitmen dengan manhaj al-taisir dalam tulisan-tulisan, fatwa dan pengajaran. Saya akan mengambil yang mudah dalam masalah furu' (cabang) dan tegas dalam masalah usul (pokok). Jika dalam satu masalah terdapat dua pandangan yang berbeda dan dua pendapat yang sama atau berdekatan, salah satu diantaranya penuh kehati-hatian, sedangkan yang satu lagi lebih memudahkan, maka selayaknya bagi kita untuk memilih fatwa yang lebih mudah bagi seluruh manusia dan jangan mengambil yang lebih hati-hati.

4. Mempersempit ruang lingkup kemudahan dalam masalah-masalah yang wajib dan yang haram

Hukum wajib dan haram adalah hukum yang sangat berat di sisi Islam, maka tidak sepatutnya menentukan sesuatu itu dengan hukum wajib atau haram kecuali dengan dalil yang pasti dan jelas. Atas dasar ini ruang lingkup yang wajib dan yang 
haram sedikit dan terbatas berbanding dengan yang boleh (ruang lingkupnya sangat luas). Maka dalam proses penerapan hukumnya juga secara bertahap seperti proses pengharaman arak (al-Qaradawi, Taysir, 29). Sementara prinsip dalam Islam adalah meringankan beban dan memperluas koridor yang dimaafkan sebagai bentuk rahmat bagi seluruh alam, maka keluasan ruang lingkup perkara-perkara selain wajib dan haram inilah bentuk kemudahan dalam hukum Islam seperti yang dinukilkan dari banyak ayat al-Qur'an dan hadis Nabi SAW (Rahman, 2008: 334-42).

\section{Membebaskan diri dari fanatisme mazhab}

Ini bermakna membebaskan diri dari keterikatan kepada salah satu mazhab tertentu yang kita ambil sebagai dalil dan bujah dalam segala masalah dalam masalah ibadah maupun masalah mu'amalah walaupun mengandungi kesulitan dan penyempitan atau telah nyata bahwa dalil yang digunakan mazhab tersebut adalah lemah berbanding dengan dalil mazhab lain. mazhab tertentu mungkin telah menyempitkan ruang terhadap masalah yang kita hadapi, namun syari'ah dengan nasnasnya dan maksud-maksudnya serta semua mazhab yang ada dan khazanah warisan para fuqahanya mengandung keluasan dan fleksibeliti yang mampu memberikan solusi bagi setiap masalah dan persoalan dan mampu memberikan rawatan pada setiap penyakit.

6. Kemudahan dalam segala perkara yang susah dielakkan

Kemudahan bisa diterapkan untuk menghadapi perkara yang susah dielakkan (ma ta'ummu bihi al-balwa) seperti banyak dijelaskan dalam kitab fiqh seperti sucinya kencing dan najis hewan yang boleh dimakan, kenajisan air berdasarkan perubahan 
air, jual beli berasaskan ridha tanpa ucapaan ijab kabul (bai' al-mu'atab) dan lain-lain masalah yang berlegar di sekeliling kita yang susah dielakkan (al-Qaradawi, Taysir, 24). Perkara umum al-balwa ini memang tepat dikatagorikan dalam fiqh al-taisir, karena dalam kondisi -kondisi itu memerlukan hukum yang longgar dan luas. Hal ini sesuai dengan kaedah fiqh (al-amru iza daqa ittasa'a) dan maqasid al-shari'ah ('adam alhara).

\section{Menjaga maqasid}

Penjagaan maqasid yang global dalam rangka merealisasikan maslahat kepada manusia baik di dunia maupun di akhirat adalah sesuatu yang dituntut. Disamping itu juga dituntut untuk menolak segala perkara yang merusak dan segala bentuk kejahatan. Hal ini bisa terlaksana dengan baik apabila adanya pemerhatian yang holistic antara nas yang spesifik (al-juz'i) dan maqasid yang global sebagai rub al-shari'ah (al-kulli). Pendekatan maqasidi ini sebagai bentuk kemudahan dan keluasan Islam seperti yang difahami oleh generasi awal para sahabat.

\section{Perubahan fatwa}

Pemutusan fatwa berdasarkan waktu dan tempat dan terus berjalan dari waktu ke waktu dan dari satu kondisi ke kondisi yang lain. Inilah keluasan, kemudahan dan fleksibelnya hukum Islam. Penjagaan maqasid dan perubahan fatwa kedua-duanya sesuai dengan metodologi para Salaf al-Shalih yang menjadi uswah hasanah bagi kaum Muslimin hari ini.

Mengambil pandangan yang mudah adalah pilihan bagi seseorang dalam mengamalkan tuntutan agama dan sah-sah saja selagi dalam masalah itu ada beragam pandangan ulama (masalah furu) seperti yang dijelaskan dalam turath kita (fiqh 
mazahib), namun hal ini tidak berlaku dalam masalah-masalah yang qat'i dan tidak boleh dilakukan dalam semua hal dan setiap keadaan. Artinya pandangan al-Qaradawi yang menyatakan adanya kemudahan dalam semua masalah itu perlu dikaji lebih teliti, jika tidak, akan terjebak ke dalam golongan yang menganggap mudah dalam semua hal dalam agama (al-mutasahilin) dan rusaklah aturan yang disusun oleh para ulama usul fiqh (pembagian hukum 'azimah dan hukum rukbsah).

Konsep taisir dalam hukum Islam pada awalnya diberlakukan pada kondisikondisi tertentu yang menuntut adanya kemudahan karena adanya kesulitan (mashaqqah), namun selanjutnya al-Qaradawi menggagas konsep ini dengan ruang lingkup yang lebih luas agar hukum Islam bisa menyelesaikan masalah terkini umat. Walau bagaimanapun keluasan dan kemudahan Islam ini tidak boleh digunakan sebebas-bebasnya tanpa batasan, maka para ulama usul fiqh dan para peneliti maqasid al-shariah memberikan standard atau kriteria (dawabit) dalam penggunaan konsep kemudahan (taisir) dalam hukum Islam.

Demikianlah perincian yang dibincangkan berkenaan dengan fiqh al-taisir dalam pelaksanaan (tatbiq). Adapun contohnya adalah seperti fatwa-fatwa yang terangkum dalam buku "Al-Halal wa al-Haram" yang diterjemahkan ke dalam berbagai bahasa. Ini menunjukan bahawa tindakbalas masyarakat terhadap buku itu sangat besar. Hal itu tentunya karena bahasa yang digunakan oleh al-Qaradawi sangat mudah dan senang difahami. Bahkan banyak kalangan ulama yang membaca buku ini dengan kekaguman yang tinggi, karena mereka mengerti benar apa yang ditulis. Selain buku "Al-Halal wa al-Haram" beliau juga menulis buku "Taysir Figh al-Siyam" dimana buku itu mengandungi dua kemudahan, yaitu kemudahan dari sisi pemahaman dan 
kemudahan dari sisi pengamalanya. Dimana bahasa yang digunakanya begitu mudah sehingga buku itu boleh menutup kekosongan yang ada di perpustakaanperpustakaan Islam yang ada. Karena masalah puasa adalah masalah yang sangat dinamik dan selalu diperlukan oleh kaum muslimin. Selain dari buku-buku itu masih ada buku-buku lain dalam bidang ini, antara lain: buku "Fatawa Mu'asirah" yang berisi beraneka macam masalah dalam kehidupan baik secara individu, bermasyarakat bahkan dalam kehidupan bernegara, "Fatawa al-Mar'ab", Malamih al-Muslim" yang di dalamnya ada pembahasan tentang figh, dan lain-lain buku al-Qaradawi dalam bidang ini yang masih banyak lagi.

Dalam penggunaan fiqh al-taisir ini, al-Qaradawi mendapatkan kritikan orangorang yang tidak sefahaman dengan dirinya, seperti yang dilontarkan oleh Sulaiman bin Salih al-Khurashi yang mengkritik manhaj fiqh yang dipegangnya, katanya: "Aliran ini cenderung "suka menggampangkan" (mengambil mudah) dalam masalah fiqh, membangun pemikiran "Islam Universal", cenderung menggunakan akal dalam memahami nas-nas syari'ah, menggunakan istilah ijtihad dan pembaharuan" (alKhuraishi, 2003: 23).

Berbagai kritikan yang dilontarkan kepada al-Qaradawi dalam hal ini, beliau memberikan ulasan tentang kemudahan dalam fiqh atau fatwa yang diusungnya, katanya:

Yang dimaksud dengan kemudahan bukanlah mempermudabkan dan meremehkan atau mengurang-ngurangkan ataupun tidak memperhatikan dan melanggar perintah Allah serta nas-nas syariah. Yang dimaksud dengan kemudahan adalab kecenderungan memberikan fatwa dan pandangan kepada yang lebih mudah bagi orang-orang yang telab mukallaf. Ini berlaku jika masalabnya berada dalam koridor ijtibad atau ada nas yang masih terbuka dengan penafsiran (Bastomi, 2014: 180). 
Dari pernyataan al-Qaradawi ini, menurut penulis jelas bahwa fiqh al-taysir yang diusung oleh al-Qaradawi sebenarnya tidak bebas tanpa batasan seperti yang mereka (para pengkritik) fikirkan. Mereka menggambarkan seolah-olah al-Qaradawi membawa perkara bid'ah dalam pemikiran fiqh. Padahal al-Qaradawi meneruskan apa yang dibuat oleh para tokoh sebelumnya walaupun ada sedikit perbedaan dalam cara dan pendekatan, namun intinya sama yaitu memberi kemudahan kepada umat Islam. Diantara tokoh yang mengusung ide ini adalah Sayyid Sabiq dengan bukunya yang sangat terkenal "Fiqh al-Sunnab". Dia menguraikan fiqh dengan cara yang mudah dan simple (tidak bertele-tele) dengan tujuan agar mudah difahami oleh kalangan umum dan bisa memuaskan kalangan khusus. Menurut Hepi Andi Bastoni terbitnya buku "Fiqh al-Sunnab" Sayyid Sabiq ini adalah hasil saran dari Imam Hasan al-Banna. Bahkan Imam Hasan al-Banna telah mendahului Sayyid Sabiq, sebab sebelumnya dia telah menulis siri makalah yang telah diterbitkan oleh majalah mingguan al-Ikhwan al-Muslimun pada tahun 1932 dengan judul "al-fiqh wa al-Usul". Sebelum makalah ini ditulis dia telah menulis makalah dengan judul "Bagaimana saya menulis masalah agama" untuk harian al-Ikhwan al-Muslimun. Dalam makalah itu Imam Hasan al-Banna menerangkan manhajnya dalam penulisan fiqh yang dibagikan kepada tiga tahap. Diantaranya ada yang ditulis untuk orang umum dan yang tidak belajar agama secara khusus. Kemudian dia menulis tentang masalah bersuci, masalah shalat, puasa dan zakat. Karya ini belum sempat selesai, sebagaimana tidak selesainya karya-karya ilmiah Hasan al-Banna yang lain. ini berarti fiqh al-taisir ini telah dirintis oleh Imam Hasan al-Banna dan dia mengajarkan kepada murid-muridnya bagaimana cara menulis fiqh yang mudah difahami oleh semua kalangan sebagaimana yang 
ditulis dalam majalah mingguan al-Ikhwan al-Muslimun. Setelah Hasan al-Banna tidak aktif lagi menulis karena kesibukanya, dia digantikan oleh Syeikh Muhammad Buhairi, kemudian oleh Syeikh Muhammad al-Hadi 'Atiyyah (seorang pengacara terkenal). Setelah itu baru digantikan oleh Syeikh Sayyid Sabiq yang kemudian menulis Fiqh alSunnah (Bastomi, 2014: 180).

\section{E. KESIMPULAN}

Dari kajian ini dapat disimpulkan seperti berikut:

1. Fiqh al-taisir adalah di antara metode yang digunakan oleh Yusuf al-Qaradawi dalam mengeluarkan fatwa dan pandangan fiqhnya.

2. Kepentingan figh al-taisir pada masa kini diperlukan oleh umat Islam sebagai solusi dalam menghadapi isu-isu yang berkembang.

3. Istilah figh al-taisir adalah trobosan baru yang digagas oleh al-Qaradawi sebagai langkah reformasi terhadap hukum Islam, supaya hukum Islam terus eksis sebagai solusi alternative sesuai dengan tuntutan zaman, tetapi prinsip dan kaedahnya sudah dirintis oleh para tokoh sebelumnya.

4. Fiqh al-taisir adalah implementasi daripada maqasid al-shari'ah, karena filosofi dari pada figh al-taisir adalah menghilangkan kesusahan (raf' al-haraj). Sedangkan raf' alharaj adalah bagian dari dar' al-mafasid yang menjadi inti dari pada maqasid alshari'ah (jalb al-masalih wa dar' al-mafasid).

5. Adapun figh al-taisir menurut al-Qaradawi adalah: mempermudah terhadap pemahaman Islam bagi seorang muslim dan juga mempermudah dalam 
melaksanakan hukum-hukumnya serta menghindari sikap memberatkan dan menyusahkan diri dalam memilih pendapat-pendapat yang ada di dalam Islam.

6. Sementara yang menjadi landasan pemikiran figh al-taisir adalah ayat-ayat alQur'an yang berisi tentang khabar gembira bukan memberi ketakutan dan HadisHadis yang menggambarkan syari'at Islam ditegakan atas dasar kemudahan.

7. Formula fiqh al-taisir yang digagas oleh al-Qaradawi meliputi dua sisi yaitu sisi pemahaman dan sisi pelaksanaan. Sisi pemahaman terdiri dari: penyatuan antara kemudahan dan kesederhanaan, kemampuan berkomunikasi dengan cara berfikir orang modern, menggunakan pengetahuan modern, standard dan istilahistilahnya. Selain itu juga menghubungkan fiqh dengan realitas dan membuang yang tidak berhubungan, menerangkan hikmah disyari'atkanya suatu hukum, menghubungkan antara satu hukum dengan hukum yang lain, meringankan tambahan dalam ibadah, mengambil faedah dari tulisan-tulisan masa kini, mengklasifikasi buku-buku, pemberian nomor dan simbol-simbol yang lain serta pencantuman indek dan yang terakhir menggunakan istilah yang ada dalilnya.

8. Semua terma ini sesuai dengan pemikiran generasi sekarang dan tidak ada kejanggalan dalam figh taisir dalam pemahaman ini bahkan sesuai dengan prinsip maqasid dan prinsip Islam itu sendiri. Namun ada klausa yang menimbulkan kontroversi dan melawan arus pemikiran fiqh para ulama yaitu tentang penggunakan istilah yang ada dalilnya. Klausa ini sepatutnya tidak perlu dimasukan dalam figh al-taisir, karena penggunakan istilah-istilah fiqh itu bukan perkara yang mendasar dalam fiqh, sebab penggunaan istilah itu tidak signifikan dan bersifat relatif. Terkadang penggunaan istilah berbeda antara satu mazhab 
dengan mazhab yang lain. Perkara ini sedia maklum dan tidak menimbulkan masalah selama ini.

9. Adapun fiqh al-taisir dalam amalan dan prakteknya dapat direalisasikan oleh alQaradawi dengan beberapa point, di antaranya: memperhatikan sisi keringanan atau rukhsah, memperhatikan keadaan yang mendesak (darurat) dan keadaan yang meringankan, memilih yang paling mudah bukan yang paling berhati-hati di zaman ini, terbatasnya masalah-masalah yang wajib dan yang haram, membebaskan diri dari fanatisme mazhab dan kemudahan dalam masalah yang susah dielakkan, penentuan maqasid dan perubahan fatwa.

10. Penerapan fiqh al-taysir al-Qaradawi ini sesuai dengan metode yang diidamkan umat saat ini untuk menyelesaikan isu umat Islam. Namun dalam penggunaanya hendaklah menurut isu tertentu dan keadaan tertentu bukan pada semua isu dan keadaan. Maka manhaj ulama usul dan maqasid al-shari'ab hendaknya dijadikan sebagai tolak ukur baik dalam teori maupun dalam pelaksanaannya.

11. Secara umum, fiqh al-taysir yang diusung oleh Yusuf al-Qaradawi boleh digunapakai sebagai dasar dalam pengeluaran fatwa, walau bagaimanapun ada beberapa hal yang perlu diperhatikan dengan teliti dan terperinci agar tidak tergelincir dari garis panduan Islam yaitu manhaj yang digunakan oleh para ulama yang mu'tabar. Antara yang perlu mendapat perhatian adalah dalam penggunaan figh al-taysir hendaknya digunakan menurut isu tertentu dan keadaan tertentu bukan pada semua isu dan keadaan. Justru, manhaj ulama usul dan maqasid alshari'ab hendaknya dijadikan sebagai tolak ukur baik dalam teori maupun dalam pelaksanaannya. Penggunaan fiqh al-taisir dengan betul dan sesuai dengan aturan 
akan menyelesaikan banyak masalah dan membuktikan bahawa Islam sebagai ajaran yang membawa misi rabmatan li al-alamin.

\section{DAFTAR PUSTAKA}

'Abd al-Karim Zaydan, Usul al-Da'wah (Beirut: Mu’assasah al-Risalah, 1987).

'Abd al-Latif al-Humayyin, Al-Daruri fi Ilm Usul al-Fiqh (Jordan: Dar 'Ammar, 2004).

'Abd al-Rahman Ibn Jawzi, Talbis Iblis (Beirut: al-Maktab al-Islami, t.t.).

'Abdullah Yahya al-Kamali, Maqasid al-Shari'ah fi Daw'i Fiqh al-Muwazanat (Beirut: Dar Ibn Hazm, 2000).

'Ali Ahmad al-Nadwi, Al-Qawa'id al-Fiqhiyyah (Beirut: Dar al-Qalam, 2013).

'Ilal al-Fasi, Maqasid al-Shari'ah al-Islamiyyah wa Makarimuba (Kairo: Dar al-Salam, 2013).

'Isam Talimah, Yusuf al-Qaradawi: Kalimat fi Takrimih wa Bubuth fi Fikrih wa Fiqhih, vol. 2 (Al-Qahirah: Dar al-Salam, 2004).

A Ilyas Ismail, Inilah Prinsip Kemudahan dalam Islam, Republika. $\quad$ https://www.republika.co.id/berita/duniaislam/hikmah/12/04/15/m2htj2-inilah-prinsip-kemudahan-dalam-islam. 
Abdul Munir Yacoob, Perkembangan Institusi Mufti di Malaysia, Kertas Kerja Seminar Serantau Mufti dan Fatwa, Institut Kefahaman Islam Malaysia (IKIM), 23 \& 24 September.

Abu 'Amr 'Uthman bin 'Abd al-Rahman al-Ma'ruf bi Ibn al-Salah al-Shaharzuri, Adab al-Mufti wa al-Mustafti (Maktabah al-'Ulum wa al-Hikam, 1986).

Abu Bakar Ibn Qayyim al-Jawziyyah, I'lam al-Muwaqqiin (Al-Qahirah: Maktabah alKulliyyat al-Azhariyyah, 1388).

Abu Hamid Muhammad ibn Muhammad bin Muhammad al-Gazali, Al-Mustasfa min IIm al-Usul (Beirut: Dar Ihya al-Turat al-'Arabi, 1993).

Abu Ishaq al-Shatibi, Al-Munafaqat, vol. 3 (Beirut: Dar al-Kutub al-'Ilmiyyah, 2005).

Ahmad 'Ali Taha Rayyan, Dawabit al-Ijtibad wa al-Fatwa (al-Qahirah: Jabhah 'Ulama alAzhar, 1994).

Ahmad al-Raysuni, Nazariyyah al-Maqashid ind al-Imam al-Shathbi (Kairo: Dar alKalimat Li al-Nasyri Wa al-Tawzi', 1997).

Ahmad bin Muhammad bin Mansur al-'Udaini, Membongkar Kedok al-Qaradawi: Shubhat Penyimpangan al-Qaradawi dari Islam dan Bantahanya (Jogjakarta: Pustaka Salafiyah, 2011).

Ahmad bin Yahya bin Muhammad al-Najmi, Mengenal Tokoh-Tokob Ikhwan al-Muslimin (Malang: Cahaya Tauhid Press, 2009).

Ahmad Bu'ud, Fiqh al-Waqi' (Al-Qahirah: Dar al-Salam, 2006). 
Al-'Iz bin 'Abd al-Salam, Qawa'id al-Ahkam fi Masalih al-Anam (Dar al-Jabl, t.t.)

Al-Khatib al-Bagdadi, al-Faqih wa al-Mutafaqqih (Beirut: Dar al-Kutub al-'Ilmiyyah, 1395).

Al-Nawawi, Sharkh al-Nawawi ala Sabib Muslim (al-Qahirah: Dar Ihya al-Turat al'Arabi, t.t.).

Al-Sayyid Husain Muhammad al-Mallah, Al-Fatwa Nash'atuba wa Tatawwaruba, Usuluba wa Tatbiqatuha (Beirut: Al-Maktabah al-'Asriyyah, 2001).

Al-Sayyid Rashid Rida, Tafsir al-Manar (al-Qahirah: Matba'ah al-Manar, 1373).

Al-Yasa' Abubakar, Metode Istislabiyyah: Pemanfaatan Ilmu Pengetabuan Dalam Usul Fiqh (Jakarta: Prenadamedia Group, 2016).

Basri bin Ibrahim al-Hasani al-Azhari, Metode Fatwa al-Qaradawi Dalam Menangani IsuIsu Semasa (Batu Caves: Al-Hidayah Publication, 2011)

Galen, L. W. (2012). Does religious belief promote prosociality? A critical examination. Psychological bulletin, 138(5), 876.

Hepi Andi Bastoni, Meneladani Kebidupan Al-Imam Prof Dr Yusuf al-Qaradawi (Kuala Lumpur: Alam Raya Enterprise SDN BHD, 2014).

Ibn Najim, Al-Ashbah wa al-Nazair.

Ibnu Farhun, Tabsirah al-Abkam (Beirut: Dar al-Kutub al-'Ilmiyyah, 1301).

Ibnu Hajar al-'Asqallani, Fath al-Bari Sharh Sabih al-Bukhari (Beirut: Dar al-Fikr, tt). 
Imaduddin Rahmat, Arus Baru Islam Radikal: Transmisi Revivalisme Islam Timur Tengah ke Indonesia (Jakarta: Penerbit Erlangga, t.t.).

Jalal al-Din 'Abd al-Rahman Bin Abi Bakr al-Suyuti, Al-Ashbah wa al-Nazair (Beirut: Dar al-Fikr, t.t.).

Jasser Awda, Maqasid al-Shariah: A Beginner's Guide, terj. Marwan Bukhari Hamid, Memahami Maqasid al-Shari'ah (Batu Caves: PTS Islamika SDN BHD, 2014).

Jawatankuasa Kompendium Maqasid al-Shari'ah, Kompendium Maqasid al-Shari'ah.

M. Amin Abdullah, "Kata pengantar", dalam Jasser Awda, Membumikan Hukum Islam Melalui Maqasid Syariah: Pendekatan Sistem (Bandung: Mizan, 2014).

Mahsun Fuad, Hukum Islam Indonesia: Dari Nalar Partisipatoris Hingga Emansipatoris (Yogyakarta: LKIS, 2005)

Childs, P. Modernism. (London: Taylor \& Francis, 2016).

Mas'ud Sabri, Al-Ifta' Inda al-Shaikh al-Qaradawi: al-Manhaj wa al-Tatbiq, Multaqa alImam al-Qaradawi, Hotel Ridezt Calton, Doha, 14-16/7/2007.

Mohd Anuar Ramli, et al, "Pemakaian Maqasid al-Shari’ah Sebagai Seismografi Dalam Penilaian Isu Semasa", dalam Noor Naemah Abdul Rahman, et al, Maqasid al-Shari'ab: Konsep dan Pendekatan (Kuala Lumpur: Jabatan Fiqh dan Usul, Akademi Pengajian Islam, Universiti Malaya, 2016).

Mohd Rumaizuddin Ghazali, Yusuf al- al-Qaradawi dan Pengarubnya dalam Masyarakat Islam di Malaysia. (Bandar Baru Nilai: Universiti Sains Islam Malaysia, 2013). 
Muhammad Abu Zahrah, Usul al-Figh (al-Qahirah: Dar al-Fikr al-'Arabi, t.t.).

Muhammad al-Tahir ibn 'Ashur, Maqasid al-Shari'ah al-Islamiyyah (t.t : al-Bashair li alIntaj al-'Ilm, 1998 ).

Muhammad Ibn Rushd al-Qurtubi, Fatawa Ibn Rushd, vol. 3 (Bayrut: Dar al-Garb alIslami, t.t.).

Muhammad Rawwas dan Hasin Sadiq Qasibiyy, Mu'jam Lugah al-Fuqaha (Dar alNafa'is, 1985).

Musa Zaid al-Kailani, al-Harakat al-Islamyyah fi al-Urdun: Dirasat wa Ikhwan al-Muslimin, Hiz̧b al-Tahrir al-Islami (Amman: Dar al-Bashar li al-Nashr wa al-Tawzi', 1990).

Mustafa 'Abdul Rahman, Hadis 40 (Shah Alam: Dewan Pustaka Fajar, 2008).

Nashwan 'Abduh Khalid al-Mikhlafi, “Asbab al-Taisir fi al-Fatawa wa Tatbiqatuha alMu'asirah", Jurnal Fiqh 8, (2011)

Norenzayan, A., \& Shariff, A. F. (2008). The origin and evolution of religious prosociality. science, 322(5898), 58-62.

Nuruddin Mukhtar al-Khadimi, Ilm Maqasid al-Shari'ab (Riyad: Maktabah al-Abikah, 1421).

Preston, J. L., Ritter, R. S., \& Ivan Hernandez, J. (2010). Principles of religious prosociality: A review and reformulation. Social and Personality Psychology Compass, 4(8), 574-590. 
Qutb Al-Raysuni, Al-Taysir al-Fiqhi: Mashru'iyyatuh wa Dawabituh wa 'Awa'iduh (Beirut: Dar Ibn Hazm, 2007).

Sa'di Abu Jayb, al-Qamus al-Fiqhi Lugatan Wa Istilahan (Dimasyq: Dar al-Fikr, 1988).

Saroglou, V. (Ed.). (2013). Religion, personality, and social behavior. Psychology Press.

Sayf al-Din Abu al-Hasan 'Ali ibn Abi 'Ali ibn Muhammad al-Amidi, Al-Ihkam fi Usul al-Ahkam (Lubnan: Dar al-Kutub al-'Tlmiyyah, 1980).

Shah Waliyullah al-Dahlawi, Hujjah Allah al-Balighah (al-Qahirah: Dar al-Jail, t.t.)

Shams al-Din Abi Abdillah Muhammad ibn Abi Bakr al-Zari ibn Qayyim alJawziyyah, I'lam al-Muwaqqi'in 'an Rabb al-'Alamin (Beirut: Dar al-Kutub al'Ilmiyyah, 1996).

Shihab al-Din al-Qarafi, al-Ahkam li Tamyizal-Fatawa 'an al-Abkam (Halab: Maktabah al-Matbu'ah al-Islamiyyah, 1387).

Sulayman al-Ashar, Al-Futya wa Minhaj al-Ifta' (Kuwayt: Maktabah al-Manar alIslamiyyah, 1396).

Sulayman bin Salih al-Khurashi, Pemikiran Dr. Yusuf al-Qaradawi dalam Timbangan, (Bogor: Pustaka Imam al-Shafi'i, 2003).

Wahbah al-Zuhayli, Usul al-Fiqh al-Islami (Damaskus: Dar al-Fikr, 2005).

Ya'qub al-Bahsin, Qa'idah al-Mashaqqah Tajlib al-Taysir (Riyad: Maktabah al-Rushd Nashirun, 2005). 
Yusuf al-Qaradawi: Al-Halal wa al-Haram fi al-Islam, (Al-Qahirah: Maktabah Wahbah, 2004).

- Al-Sahwah al-Islamiyyah baina al-Ikhtilaf al-Mashru' wa al-Tafarruq al-Mąmum (Al-Qahirah: Dar al-Shuruq, 2001).

al-Sahwah al-Islamiyyah wa Humum al-Watan al-'Arabi wa al-Islam

(Al-Qahirah: Dar al-Shuruq, 1998).

, Al-Marïizyyah al-Ulya fi al-Islam. (Al-Qahirah: Maktabah

Wahbah, 2001).

, Al-Hayah al-Rabbaniyyah wa al-Ilm. (Al-Qahirah: Maktabah

Wahbah, 1995).

, Al-Siyasah al-Shar'iyyah (Al-Qahirah: Maktabah Wahbah, 1998).

, Awlawiyyat al-Harakah al-Islamiyyah (Al-Qahirah: Muassasah al-

Risalah.

, Dirasah fi Figh Maqasid al-Shari'ah Baina al-Maqasid al-Kulliyah wa

al-Nusus al-Jur'iyyah (Al-Qahirah: Dar al-Shuruq, 2006).

, Fatawa Mua'sirah, vol. 1 (Al-Qahirah: Dar al-Wafa, 1990).

,Shumul al-Islam (Al-Qahirah: Maktabah Wahbah, 2003).

Taysir al-Figh li al-Muslim al-Mu'asir Fi Dhaw' al-Qur'an Wa al-

Sunnah (Al-Qahirah:: Maktabah Wahbah, 1999). 
Yusuf al-Qaradawi Shakhsiyyat al-'Am al-Islamiyyah (Al-Qahirah:

Maktabah Wahbah, 2001).

Zainal Abidin bin Ibrahim bin Najim, Al-Ashbah wa al-Nazair (al-Qahirah: alMaktabah al-Tawfiqiyyah, t.t.).

Zulkifli Mohamad al-Bakri, Istilah-Istilah Fiqah dan Usul Empat Marhab (Kuala Lumpur: Jabatan Kemajuan Islam Malaysia, 2010). 